https://doi.org/10.37208/tgn27314

\section{The discovery of a colony of wood sage plume Capperia britanniodactylus (Lepidoptera: Pterophoridae) in West Stirlingshire, Scotland}

\author{
M. Culshaw* \& C.J. McInerny \\ School of Life Sciences, University of Glasgow, \\ Glasgow G12 8QQ \\ *E-mail: martinculshaw121@btinternet.com
}

Plume moths (Pterophoridae) are highly distinctive, thin and unusual looking microlepidoptera. There are 44 species on the British list, all of which have the characteristic posture of standing up on their legs with wings extended at right angles to the body. The wings have long fringes and are cleft into lobes which resemble feathers (Hart, 2011).

On 7th June 2020, MC was looking for the moth dingy shell (Euchoeca nebulata), amongst stream-side alder (Alnus glutinosa) near Burncrooks Reservoir, West Stirlingshire, Scotland. During the late morning he came across a flat treeless area at the base of a steep rocky crag, facing WSW and bordered by high bracken (Pteridium spp.). Within this location were several patches of flowering wild thyme (Thymus polytrichus) which drew his eye. On closer inspection he could see a number of small "plume moths" flying above the thyme, seemingly feeding on it. MC was able to net and pot one of these moths. He did not have any detailed texts with him but did photograph the moth with his mobile phone, estimating its size in the process.

On returning home, $\mathrm{MC}$ consulted the various literature sources and informed CJM of his finding. His initial putative identification was that of Oxyptilus parvidactyla (small plume) based on both size and wing pattern. He had also noted that small plume is known for flying in afternoon sunshine and visiting wild thyme flowers (Sterling \& Parsons, 2018).

However, small plume has only rarely been recorded in Scotland (in just three vice-counties: 91, 92 and 103) so this would have represented the first record for central Scotland and the first Scottish observation for at least six years. In consultation with plume moth expert Colin Hart, MC was reminded of the importance of finding the foodplant at the moth's location to confirm the identification, since there are a number of similarly patterned plume moths that cannot be safely separated by wing pattern alone. While an accurate measurement of forewing length (FL) would possibly have been enough to assign the moths to species level, MC had not taken this and so he and CJM resolved to return to the site to search for the foodplant of small plume (mouse-ear hawkweed Pilosella officinarum) and take accurate FL measurements, and better photos.

CJM visited the site on 11th June 2020 during the early afternoon and found at least 23 of the plume moths on wild thyme and took an excellent photograph of one of them (Fig. 1). Both CJM and MC attended the site again on 14th June 2020 but could find no trace of any mouse-ear hawkweed. Instead they found ample wood sage (Teucrium scorodonia) growing side by side with the thyme (Fig. 2). MC was able to net and closely examine further individual moths and measured the FL as $9 \mathrm{~mm}$. All of this indicated that the moths were not small plume but were instead the slightly larger Capperia britanniodactylus (wood sage plume), an identification subsequently confirmed by Colin Hart. It was estimated that at least 50 moths were present including some copulating pairs.

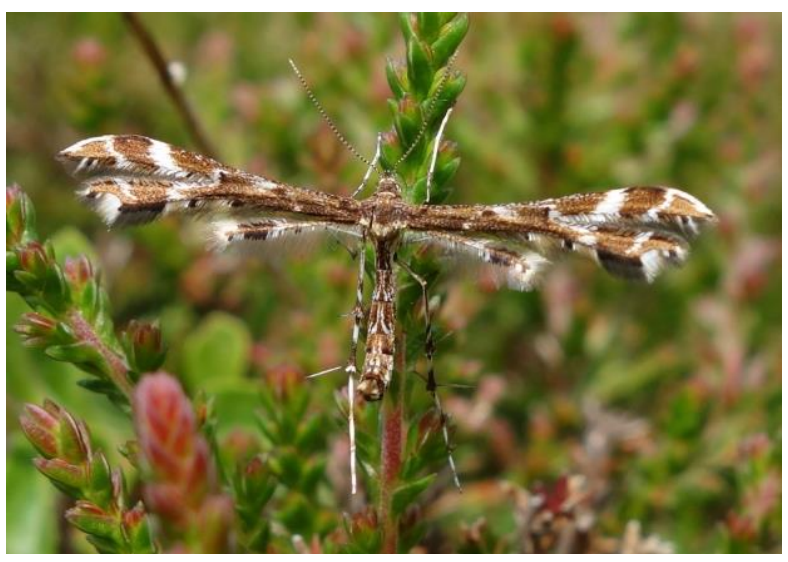

Fig. 1. Wood sage plume (Capperia britanniodactylus), Burncrooks Reservoir, West Stirlingshire, Scotland, 11th June 2020. (Photo: C.J. McInerny)

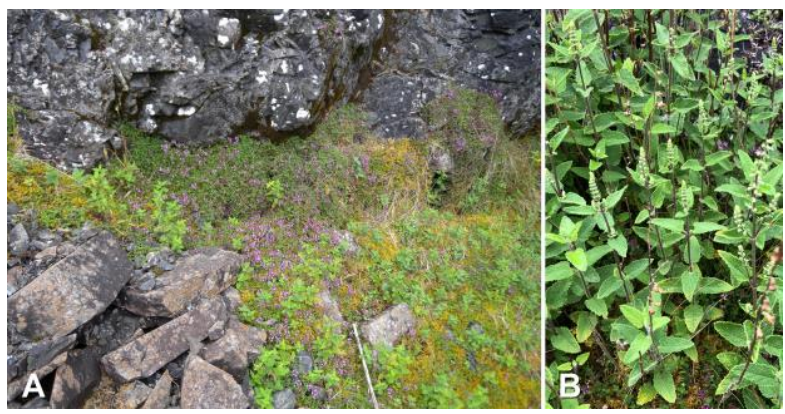

Fig. 2. Location of a wood sage plume (Capperia britanniodactylus) colony, Burncrooks Reservoir, West Stirlingshire, Scotland, 14th June 2020. (A) General view of the site. (B) Wood sage (Teucrium scorodonia), which is the host plant of $C$. britanniodactylus and can been seen along with the blue-purple flowers of wild thyme (Thymus polytrichus). (Photos: M. Culshaw) 
While not as scarce as small plume in Scotland, wood sage plume is nonetheless a notable find, having been recorded in only about half of the Scottish vice-counties, mainly in the east of the country (Cubitt, 2020). Although widely distributed in Britain, it is quite rare in most places and absent from many apparently suitable sites. This finding represents only the second record of the species in VC86 (Stirlingshire) and the first observation of a colony.

Of note is that the published literature suggests that wood sage plume adult moths hide in clumps of the foodplant during the day and are difficult to disturb, preferring to take flight at dusk (Hart, 2011). This contrasts with our observation of many moths flying in the late morning and early afternoon when it was warm, in overcast as well as sunny conditions.

The initial finding on 7th June also indicates a relatively early emergence date for the species, more in keeping with that in southern Britain, although even there the main emergence is normally July. We suggest that this may have been due to the prolonged period of hot weather in central Scotland in May and early June 2020. The location was a "sun trap" with patches of wild thyme and wood sage growing side by side, providing apparently ideal habitat (Fig. 2).

We thank Colin Hart for help in identifying the plume moth.

\section{REFERENCES}

Cubitt, M. (2020). Scottish Micro Moth Distribution Maps. Butterfly Conservation East Scotland Branch. http://www.eastscotland-butterflies.org.uk/scottish micros.html Accessed 17th July 2020.

Hart, C. (2011). British Plume Moths. British Entomological and Natural History Society, Reading.

Sterling, P. \& Parsons, M. (2018). Field Guide to the Micromoths of Great Britain and Ireland. Bloomsbury Wildlife, London. 